\title{
Assessing the Floristic Biodiversity and Carbon Stock in a Republic of Congo's Forest Ecosystem
}

\author{
Donatien Nzala1 $^{*}$, Romeo Ekoungoulou ${ }^{1,2 *}$, Bernadin Y. Ngoumba1 \\ ${ }^{1}$ Ecole Nationale Supérieure d'Agronomie et de Foresterie, Université Marien Ngouabi, Brazzaville, Republic of Congo \\ ${ }^{2}$ Beijing Key Laboratory of Forest Resources and Ecosystem Process, Beijing Forestry University, Beijing, China \\ Email: ^nzaladon@yahoo.fr, *romeoekous@gmail.com
}

How to cite this paper: Nzala, D., Ekoungoulou, R. and Ngoumba, B.Y. (2019) Assessing the Floristic Biodiversity and Carbon Stock in a Republic of Congo's Forest Ecosystem. Open Access Library Journal, 6: e5638.

https://doi.org/10.4236/oalib.1105638

Received: July 25, 2019

Accepted: August 16, 2019

Published: August 19, 2019

Copyright $\odot 2019$ by author(s) and Open Access Library Inc.

This work is licensed under the Creative Commons Attribution International License (CC BY 4.0).

http://creativecommons.org/licenses/by/4.0/

\begin{abstract}
Reforestation management goes through the knowledge of the tired out evolution after a forestry rest. The aim of this study was to assess biodiversity concerning Terminalia superba Engl. \& Diels and its undergrowth, and then quantify sequestered carbon stocks to appreciate the impact of reforestation on forest recovery and the enhancement of carbon stocks. The study was conducted at Bilala artificial forest in southeastern Republic of Congo, in Kouilou Department (Mayombe), close to Mvouti District with an altitude of $30 \mathrm{~m}$. The floristic inventory was carried out in 9 rectangular sub-plots of $20 \times$ $25 \mathrm{~m}$ each, installed in three blocks of Terminalia superba Engl. \& Diels, for a total area of 0.5 ha. These blocks consisted of the 64, 31 and 20 years old plantations. Within ten sub-plots censuses, all trees with a $\mathrm{DBH} \geq 5 \mathrm{~cm}$ were identified and measured. 51 trees of Terminalia superba Engl. \& Diels and around 3007 trees in its undergrowth have been recorded belonging to 33 botanical families and 52 species. The results showed that the biomass recorded in this forest has been $275 \mathrm{t} \cdot \mathrm{ha}^{-1}$ and the carbon stock was $129.6 \mathrm{t} \cdot \mathrm{ha}^{-1}$. Terminalia superba Engl. Diels had for itself a biomass of $181.42 \mathrm{t} \cdot \mathrm{ha}^{-1}$ out of the $275 \mathrm{t} \cdot \mathrm{a}^{-1}$ quantified. The amount of $\mathrm{CO}_{2}$ captured in the atmosphere by the recorded floristic procession deducted from this carbon stock was 475.89 tons of $\mathrm{CO}_{2}$, with an economic value equal to US $\$ 2379.45$ or XAF $1,413,278$. This study demonstrated that the forestry method of reforestation has a positive impact on biodiversity recovery and carbon sequestration.
\end{abstract}

\section{Subject Areas}

Ecology, Ecosystem Science, Environmental Sciences

\section{Keywords}

Bilala, Biomass, Carbon Stock, Reforestation, Terminalia superba 


\section{Introduction}

Tropical forests sheltered most of the world's biodiversity, accounting for $2 / 3$ of the 1.3 million recorded animal and plant species [1]. They contain $40 \%-50 \%$ of terrestrial carbon and play a major role in the global carbon cycle [2]. At the beginning of the 19th century, the world's tropical forests covered around 16 million $\mathrm{km}^{2}$. Now, they cover only around 3.8 billion hectares [3]. Since the 1992 Earth Summit, it has been established that biodiversity is seriously threatened by humans [1]. The loss of forest cover resulting from deforestation and forest degradation results in the loss of more than 13 million hectares of forests worldwide each year [4] and damages biodiversity [5]. This activity contributes actively to about $10 \%-15 \%$ of global annual greenhouse gas emissions [6].

In Republic of Congo, forests cover 22.4 million hectares divided into three major groups: the North Congo massif with 17.4 million hectares, and the Mayombe and Chaillu massifs in southern Congo with around 4.7 million hectares. These last two were the first exploited since colonial times by the reason of the Pointe-Noire carriage proximity and the presence of the CFCO (Railways Congo Ocean Company) railways and the Ogooué Mining Company [7]. This led foresters to ask themselves very early on the availability of biodiversity and the restoration of forest heritage. The creation in 1934 of the Mbuku Nsitu arboretum in the Mayombe Massif, has historically testified to the interest that some forestry services or researchers have made early in the question concerning the sustainability of Congolese forests [8]. Thus, an initiative of reforestation of the degraded zones of Mayombe began in the season 1949-1950 in order to contribute to the maintenance and the restoration of the biological diversity and productive functions of the southern Congolese forests. After independence, the Congolese government supported in 1970 through cooperation with UNESCO through the Intergovernmental Program on Man and the Biosphere (MAB) and the United Nations Development Program launched a vast development project for the Mayombe Massif [8].

Today, the Mayombe afforestation and reforestation cover an area of around 10,000 ha [9], including the reforestation of Terminalia superba Engl. \& Diels from Bilala. Covering an area of 421 hectares and set up in 1954 in open forest, these reforestations were originally intended to offset the lack of timber. However, new opportunities have emerged over time; the evolution of Bilala's reforestation has resulted in the rebuilding of the natural forest, which has led to the resettlement of biodiversity and has attracted the attention of many scientists and local populations. In a context of mitigation to the effects of climate change [10], a new potential valorization of Bilala's reforestation could be linked to its carbon sink function. Indeed, under the Kyoto Protocol ratified in December 1997, carbon credits can be granted to better conserve its forests [11] [12]. In accordance with the REDD+ (Reducing emissions from deforestation, forest degradation, and forest conservation, sustainable management of forest, and enhancement of forest carbon stocks) process set up by the Clean Development 
Mechanism of the Kyoto Protocol, the signing of a Carbon credits with the World Bank, through the Carbon Fund set up since 2011, could help the National Reforestation Service (SNR) to valorize forest carbon and boost the management of its plantations [13]. In order to benefit from the carbon-credit, it must be possible to demonstrate that reforestation contributes to increased carbon sequestration and to quantify this increase.

Studies on floristic diversity and carbon stock estimation [14] in southern Republic of Congo remains fragmented and mostly located in protected areas (Dimonika and Conkouati-Douli Reserve). They focus on general knowledge of flora [15]. They have sometimes focused on undergrowth vegetation in forest plantations [16], while others have focused on estimating the carbon stock [17] [18]. A study on the evolution of tired out after Cassava plantations [19]. As the issues are different, the results are difficult to compare [16]. There is existence of a few data on reforestation of Terminalia superba Engl. \& Diels in Republic of Congo. Those that are available focus on cuttings and spacing trials. No studies on undergrowth vegetation of Terminalia superba Engl. \& Diels reforestation has not been conducted yet. As forestry research is concerned, this current study on biodiversity, carbon stock assessment and forest management of the Bilala reforestation is the first to contribute to the knowledge of Mayombe flora in its diversity. In the context of the fight against climate change and preservation of biodiversity, How can reforestation contribute to the implementation of the REDD + process in Bilala?

The general objective of this study was to assess the biodiversity of Terminalia superba Engl. \& Diels plantations, and its undergrowth and also to quantify carbon stocks about the above-and below-ground biomass of trees in order to assess the impact of reforestation on forest regeneration and the generation of carbon stocks in order to provide the SNR (National Reforestation Service) with a tool to assist the management of plantations and local populations. The specific objectives of this study was (I) to identify, by floristic surveys, trees with $\mathrm{DBH} \geq$ $5 \mathrm{~cm}$ at $1.30 \mathrm{~m}$ from the soil, as well as the herbaceous present; (II) Quantify carbon stocks sequestered by trees with $\mathrm{DBH} \geq 5 \mathrm{~cm}$; and (III) identify bottlenecks that hinder the successful management of Terminalia superba Engl. \& Diels reforestation to propose a long-term management strategy.

\section{Materials and Methods}

\subsection{Study Area}

The study sites were located at Bilala $\left(4^{\circ} 30^{\prime} \mathrm{S}, 12^{\circ} 13^{\prime} \mathrm{E}\right)$ in southeastern Republic of Congo, in Kouilou Department (Mayombe), close to Mvouti District with an altitude of $30 \mathrm{~m}$. Bilala is bounded at the North by Bilinga, at the South by the Paris forest and the Congo-Angola international border, at the East by Tchyvala village and at the West by the coastal plain and Yanga village [20]. Thus, the research work was carried out in Bilala and its surroundings in three plantation sites under the supervision of the Mayombe station. Specifically, the three sites 
studied are: 1) the Matete1 reforestation site; 2) the Bilala site installed for the protection of the "Gutter" watershed against erosion; 3 ) the coastal plain site.

Bilala is subject to a warm and humid climate combining equatorial, tropical and oceanic traits. According to the [21] study, the climatic characteristics of Bilala are as follows: The climate is low-Congolese with a variant of the "Guinean" type; the average annual rainfall is between 1200 and $1500 \mathrm{~mm}$ [21]. The hottest month is March with an annual temperature of $27.5^{\circ} \mathrm{C}$. A rainy season from mid-October to mid-May with the highest temperature and illumination maxima of the year; it is interrupted by a small dry period which is not recognized as a dry season. A dry season from mid-May to mid-October with a lowest temperature and illumination minimums of the year. Relative humidity is always around $85 \%$; relative humidity is greater during the dry season than during the rainy season. The sky is often permanently covered with fog and clouds (Figure 1 and Figure 2). Bilala is flat and at the same time rugged. The rocks are of mainly schistose or sandstone origin, with intrusions of various crystalline rocks: granites, quartz diorites, green rocks [8]. The soils of Bilala are mostly ferralitic, poor in exchangeable bases, highly saturated and very acidic [19]. The Bilala river system is organized around the Loémé River. The village is contorted by several swamps [8].

\subsection{Data Collection}

The floristic surveys were carried out on the one hand on the monospecific stands planted with Terminalia superba Engl. \& Diels aged 64, 31 and 20, and at

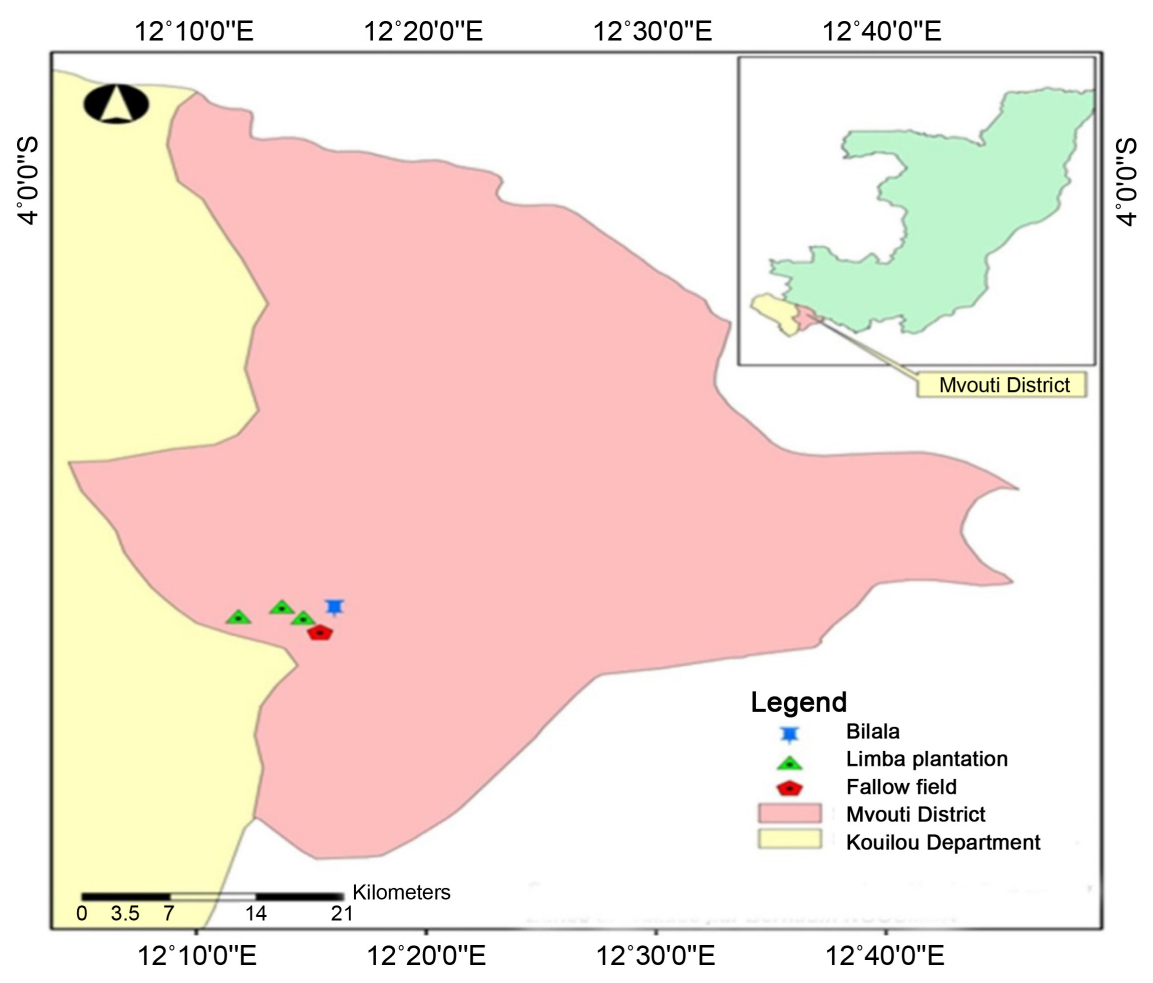

Figure 1. Study area location. 


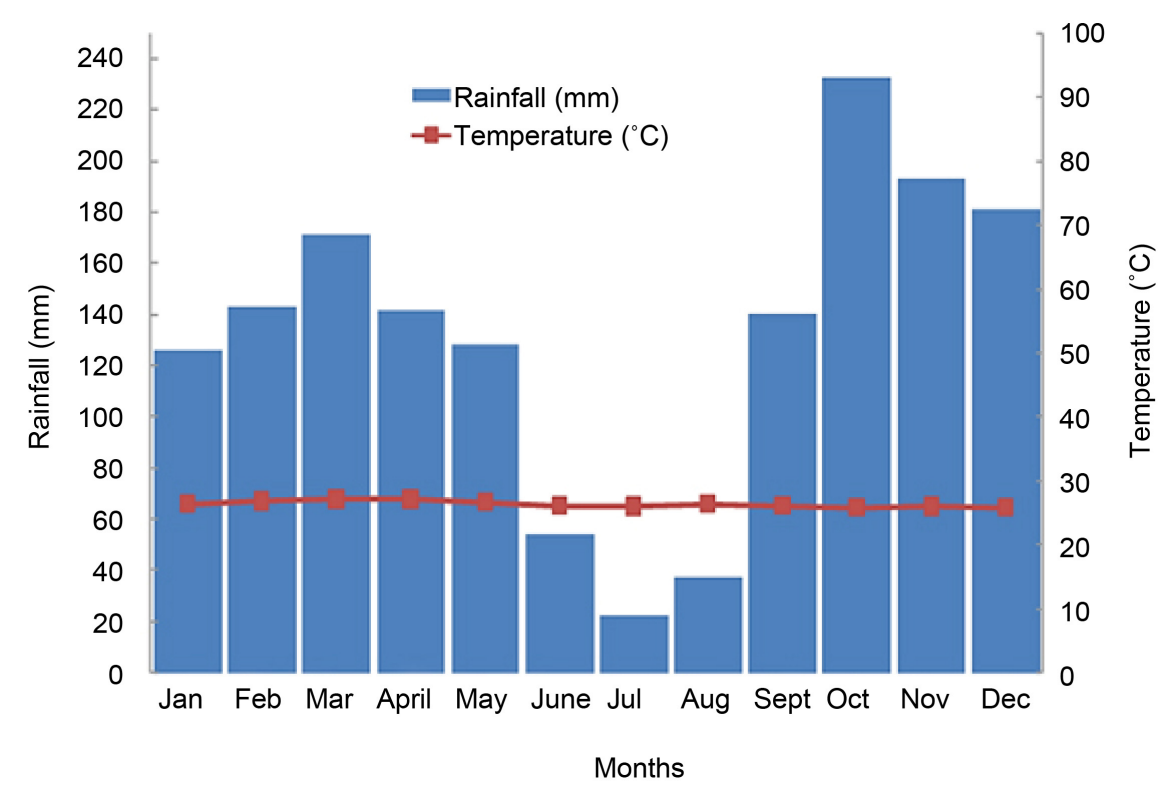

Figure 2. Climograph of Bilala provided by the meteorological station around the study area from January to December 2018.

the same time in the undergrowth of its stands. All data were collected during the period from July 16, 2018 to November 1, 2018. In the first place, the surveys were carried out on the block of Terminalia superba Engl. \& Diels planted in Matete in 1954 with an area of 421 ha and then in two stands of 31 years and 20 years of respective areas of 0.3 ha and 1 ha. Thus, in the undergrowth of its three blocks, woody, herbaceous and lianascent species served as identification and measurement support (case of woody plants).

Data collection was carried out in nine rectangular sub-plots of $20 \times 25 \mathrm{~m}$ each, installed in three blocks of Terminalia superba Engl. \& Diels still called Limba and in a fallow field, a total area of $0.5 \mathrm{ha}$. The shape of the plot was inspired by the work of [22] where the estimation and monitoring of carbon stock could be done in a temporary plot. Each sub-plot was divided into two strips of $10 \mathrm{~m} \times 25 \mathrm{~m}$ each. The floristic surveys consisted of recording each vegetative species present in the sampling area band by band and at the same time measuring all the planted or spontaneous wood specimens with a $\mathrm{DBH} \geq 5 \mathrm{~cm}$ at $1.30 \mathrm{~m}$ from the soil. For herbaceous species, counting of individuals was not done in full. However, band-by-band notes ranging from 25 to 100 individuals representing the numerical abundance of the species within the band were assigned to each herbaceous species inventoried according to the Ushuaia multiple inventory scale which is as follows:

25: slightly abundant; 50: moderately abundant; 75: abundant; 100: very abundant.

The plots were dispersed in the three blocks studied. This operation began with a careful observation of the place. The planting line was then found using the compass that gave an East-West direction. After that, the first base milestone (milestone 1) was placed next to the first tree of the planting line. Using the 
double decameter of $20 \mathrm{~m}, 20 \mathrm{~m}$ were drawn starting from milestone 1 following the South-North direction and $25 \mathrm{~m}$ following the planting line using the double decameter of $30 \mathrm{~m}$. Four basic milestones were marked at the ends of the sub-plot. Finally, the sub-plot was divided into two equal rectangular strips (10 $\mathrm{m} \times 25 \mathrm{~m}$ ) where two milestones were placed at the ends of each strip. At the end of the operation, six milestones were marked with red paint and a GPS coordinate was recorded on the first tree of the sub-plot.

Concerning woody trees, the circumference was first measured using a tape measure at $1.3 \mathrm{~m}$ from the ground and the diameter calculated on site. The diameter of the trees was measured above the buttresses or stilt roots. The height was then measured using the vertex and the species was identified. The height of considered tree was which of the highest branch. To finalized, a number was assigned in ascending order and marked with red paint to each tree measured and identified. Species identification was made with the naked eye using the following botanical characteristics: bark shape, latex color, leaf arrangement, crown shape, trunk base shape, and its termination. A manual has been used as a basis for the identification of species: Botanical Manual and Inventory of Biodiversity of the Association of International Tropical Timber Technicians [23]. Regarding the case of Ricinodendron heudelotii (Baill.) Pierre ex Pax which loss its leaves, the bark allowed the identification of the species. Thus, all trees with $\mathrm{DBH} \geq 5$ $\mathrm{cm}$ were measured, identified and counted from band 1 to band 2 and at the same time all herbaceous and lianascent species were identified. Tree species recorded in study area have been identified using earned scientific knowledge during the biosystematics courses at university. Field work experiences during the university studies period also were a help to identify flora species of study area.

\subsection{Data Analysis}

The general checklist of species composing the flora procession has been established after digital processing of nine sample sub-plots. On the basis of The African plants database (version 3.4.0) of Conservatory and botanical garden of Geneva, Switzerland \& South African National Biodiversity Institute, Pretoria (accessed 1 April 2019 at

http://www.ville-ge.ch/musinfo/bd/cjb/africa/recherche.php), The Global plants database (Accessed on 7 April 2019 at http://plants.jstor.org, The working list of all plant species database (Retrieved April 1, 2019 from http://www.theplantlist.org), and The Xycol database (The list of scientific and vernacular woods names: accessed on April 7, 2019 at

http://www.xycol.net/inde x.php?categorie=0\&sess_langue=430), all flora species were checked and confirmed. Using the above databases and websites, all identified flora species were confirmed. A diversity index is a quantitative measure that reflects how many different species there are in a community, and simultaneously take into account how evenly the basic entities (such as individuals) are 
distributed among those types. Vernacular and local nomenclatures of the species recorded in the undergrowth of the stands of Terminalia superba Engl. \& Diels were verified in the South-Congo Plant Database of the National Center for Forest Resources and Wildlife Inventories and Management [24] and tough database of "Global plants database" (Accessed April 1, 2019 at

http://plants.jstor.org and http://plantes-botanique.org). Wood density for each species has been founded from the database "global wood density database" available at http://datadryad.org/handle/10255/dryad.235 (Retrieved 10 October 2018).

\subsubsection{Analysis of Floristic Diversity}

Floristic composition and spontaneous floristic diversity were assessed using four main parameters:

1) Species richness $(R)$ which represents the total number of species recorded;

2) Absolute Abundance $(A)$ which represents the total number of individuals of a species [25];

3) The Shannon Weaver $(H)$ floristic diversity index is an index expressed in bits between 0 - 5 [26] (2). This index was obtained from the relative abundance $\left(P_{i}\right)$ of each species, which is the ratio between the total number of individuals in a survey and absolute abundance [27]. Relative abundance is given by Equation (1).

$$
P_{i}=\frac{N_{i}}{N}
$$

$N_{i}$ represent the total number of species individuals $i$ and $N$ the total number of individuals.

$$
H^{\prime}=-\sum_{i=1}^{n}\left(P_{i} \times \log 2 P_{i}\right)
$$

4) The evenness index of Pielou $(E)$ is between 0 and $1(3)$. It is the ratio between the diversity of a species and the total number of species " $S$ " of a sub-plot [28]. This index makes it possible to measure the distribution of individuals within species.

$$
E=\frac{H^{\prime}}{\log 2 \times S}
$$

\subsubsection{Distribution of Recorded Species by Diameter Class}

This part concerns all spontaneous species of diameter $\geq 5 \mathrm{~cm}$ inventoried. The diameters of the trees were obtained in the field by dividing the circumference by 3.14 [29]. These diameters were used to divide the studied stands by amplitude class.

\subsubsection{Survival Rate}

The number of plants installed being known, after inventory and measurement of the trees, we obtained the number of trees for each plot, which made it possible to calculate the survival rate given by Equation (4): 


$$
\text { Survival rate }(\%)=\frac{\text { Number of alive trees }}{\text { Total number of trees }} \times 100
$$

\subsubsection{Biomass Estimation and Carbon Stock}

1) Aboveground biomass (AGB)

The estimation of aboveground biomass was performed using the standard allometric equation developed by [30] (5). The choice of this equation was made based on the type of ecosystem in the study area and the threshold of DBH $\geq 5$ $\mathrm{cm}$. This equation has been recommended by the REDD+ process, successfully used and repeated in many studies [31] [32] [33].

$$
\mathrm{AGB}=0.067 \times\left(\rho D^{2} H\right)^{0.976}
$$

With:

$\rho:$ wood density $\left(\mathrm{g} \cdot \mathrm{cm}^{-3}\right)$;

$H$ : height of tree (m);

$D$. diameter at breast height $(\mathrm{cm})$;

AGB: aboveground biomass $\left(\mathrm{t} \cdot \mathrm{ha}^{-1}\right)$.

2) Belowground biomass

Belowground biomass was obtained from the [34] equation for tropical forests [34].

$$
\begin{aligned}
& y=0.205 \times \mathrm{AGB} \quad \text { if } \mathrm{AGB} \leq 125 \mathrm{t} \cdot \mathrm{ha}^{-1} \\
& y=0.235 \times \mathrm{AGB}
\end{aligned}
$$

So " $y$ " is belowground biomass (BGB) and AGB is aboveground biomass.

3) Total biomass

The total biomass of standing woody was obtained by adding the aboveground biomass and belowground biomass.

4) Carbon stock and ecological service value

The sequestered carbon stock was obtained by multiplying the total biomass by 0.47 [35]. The amount of carbon dioxide $\left(\mathrm{CO}_{2}\right)$ emissions was then determined by multiplying the sequestered carbon stock by the ratio $44 / 12$ corresponding to the $\mathrm{CO}_{2} / \mathrm{C}$ ratio. This is the monetary value deducted from the amount of $\mathrm{CO}_{2}$ emissions captured from the atmosphere by the identified trees. This value was obtained by evaluating the amount of $\mathrm{CO}_{2}$ in very fluctuating monetary value which is $5 \mathrm{USD} / \mathrm{t}$ eq. $\mathrm{CO}_{2}[36]$.

Data analysis has been performed using PAST v.3.05 and QGIS v.2 softwares.

\section{Results}

\subsection{Floristic Diversity Overview}

The inventory carried out in the blocks of Terminalia superba Engl. \& Diels of 64,31 and 20 years old has enabled us to record 9, 27 and 15 alive trees respectively (Table 1). Table 1 shows important differences depending on the surveys and blocks. The largest value of the diameter is observed at the level of the sub-plot 3 (P3), while that of the height is obtained at the level of the sub-plot1 
Table 1. Trees recorded in study area by sub-plot. $n$ : Number of individuals for each species recorded in study area; $\mathrm{H}$ : Average height of each tree in Bilala (m); DBH: Average of diameter at breast height for each species in study area $(\mathrm{cm})$.

\begin{tabular}{cccccc}
\hline Sub-plot & Block (year) & $n$ & DBH & H & Number of planted trees \\
\hline P1 & 64 & 4 & 56.2 & 46.2 & 4 \\
P2 & 64 & 3 & 68.4 & 40 & 4 \\
P3 & 64 & 2 & 70 & 43.5 & 4 \\
P4 & 31 & 9 & 37.6 & 23.6 & 30 \\
P5 & 31 & 7 & 40.3 & 22 & 30 \\
P6 & 31 & 11 & 38.9 & 19.8 & 30 \\
P7 & 20 & 6 & 28.9 & 24 & 9 \\
P8 & 20 & 5 & 36.3 & 31.3 & 9 \\
P9 & 20 & 4 & 35.6 & 29 & 9 \\
\hline
\end{tabular}

(P1). The 64-year-old blocks have an average diameter of $65.28 \mathrm{~cm}$ and an average height of $44.5 \mathrm{~m}$. Floristic surveys carried out in the block of Terminalia superba Engl. \& Diels aged 64, 31 and 20 years; and in the fallow field, the total of 62 species belonging to 36 families, around 3586 individuals. These species consist of woody, herbaceous and lianascent plants. Table $2 \&$ Table 3 present the richness and floristic diversity of the studied blocks.

Table 2 shows that the number of individuals varies from 40 to 596. Species richness varies from one survey to another. In the fallow field, there are around 579 individuals in 13 families and 18 species. The large value was obtained in P3 and P8 (18 species). The Shannon diversity index and Pielou evenness ranged from 1.30 to 2.44 bits and 0.35 to 0.77 , respectively, in all Terminalia superba Engl. \& Diels surveys. In the fallow field, diversity is very important with a value of 3.02. Table 3, however, shows that the number of individuals varies between 680 and 1329 . The family number varies between 10 and 24 . Species richness in turn varies from 12 to 33 species. The greatest species richness is observed in 20 -year-old and 64-year-old blocks with 27 species in 22 families. The lowest species richness is observed in 31-year-old blocks (12 species in 10 families). Thus, in the undergrowth of Terminalia superba Engl. \& Diels, the floristic inventory yielded around 3007 individuals in 33 families and 52 species. However, Shannon indices ranged from 1.81 to 1.97 bits. The highest value is observed in the 31-year-old sub-plot. The Pielou index varies from 0.47 to 0.61 . The highest average value of the Pielou index goes back to the 31 -year-old sub-plot. The high values of the Shannon diversity indices and Pielou evenness shows that its stands are diverse and the individuals are well distributed among the species.

Figure 3 shows the percentages of species per family for the 64, 31 and 20 year old blocks. Figure 3(a) shows that 9 out of 22 families represent more than $67 \%$ of species. The most represented families are Burseraceae with $12 \%$ of species, followed by Euphorbiaceae with 10\%, Moraceae with $8 \%$, Rutaceae and Sapotaceae with $7 \%$ each. The Arecaceae family with $5 \%$ of species ranks last. The term 
Table 2. Specific richness and diversity indices of the different surveys.

\begin{tabular}{cccccccccc}
\hline Survey & P1 & P2 & P3 & P4 & P5 & P6 & P7 & P8 & P9 \\
\hline Specific richness & 8 & 14 & 19 & 7 & 6 & 9 & 16 & 19 & 18 \\
Numerous abundance & 360 & 254 & 468 & 331 & 354 & 554 & 596 & 40 & 44 \\
Shannon index & 1.93 & 1.30 & 2.25 & 1.68 & 1.80 & 2.444 & 1.92 & 2 & 1.94 \\
Pielou index & 0.64 & 0.35 & 0.52 & 0.60 & 0.70 & 0.77 & 0.48 & 0.47 & 0.46 \\
\hline
\end{tabular}

Table 3. Specific richness and diversity index of studies blocks.

\begin{tabular}{cccccc}
\hline $\begin{array}{c}\text { Blocks } \\
\text { (years) }\end{array}$ & $\begin{array}{c}\text { Number of } \\
\text { individuals }\end{array}$ & $\begin{array}{c}\text { Number of } \\
\text { families }\end{array}$ & $\begin{array}{c}\text { Number } \\
\text { of species }\end{array}$ & $\begin{array}{c}\text { Shannon index } \\
\text { (average) }\end{array}$ & $\begin{array}{c}\text { Pielou index } \\
\text { (average) }\end{array}$ \\
\hline 64 & 1008 & 22 & 27 & 1.81 & 0.50 \\
31 & 1329 & 10 & 12 & 1.97 & 0.61 \\
20 & 680 & 24 & 33 & 1.95 & 0.47 \\
Total & 3007 & 36 & 61 & & \\
\hline
\end{tabular}

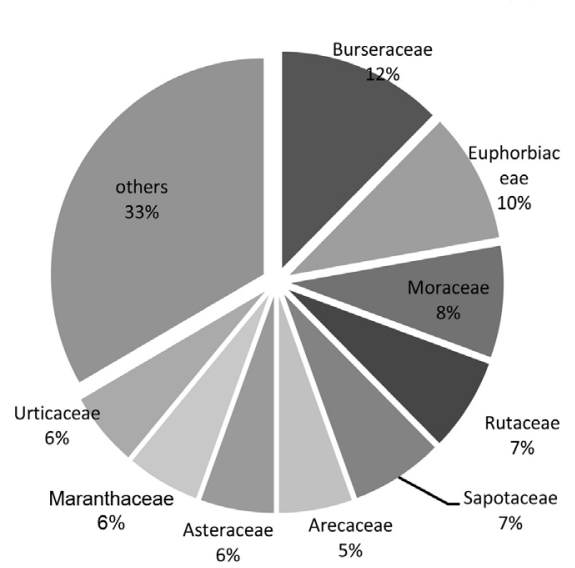

(a)

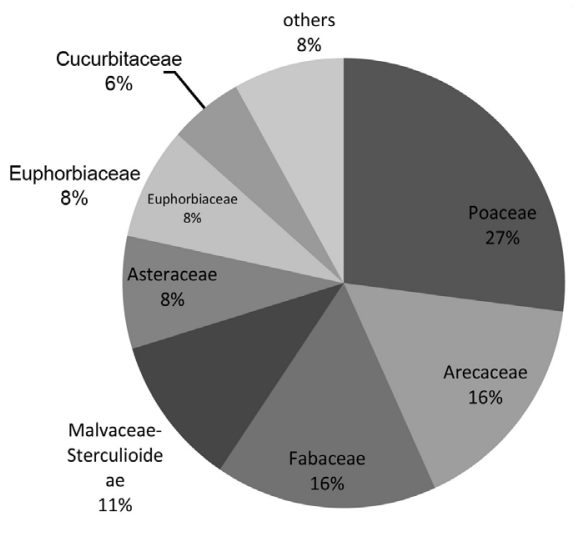

(b)

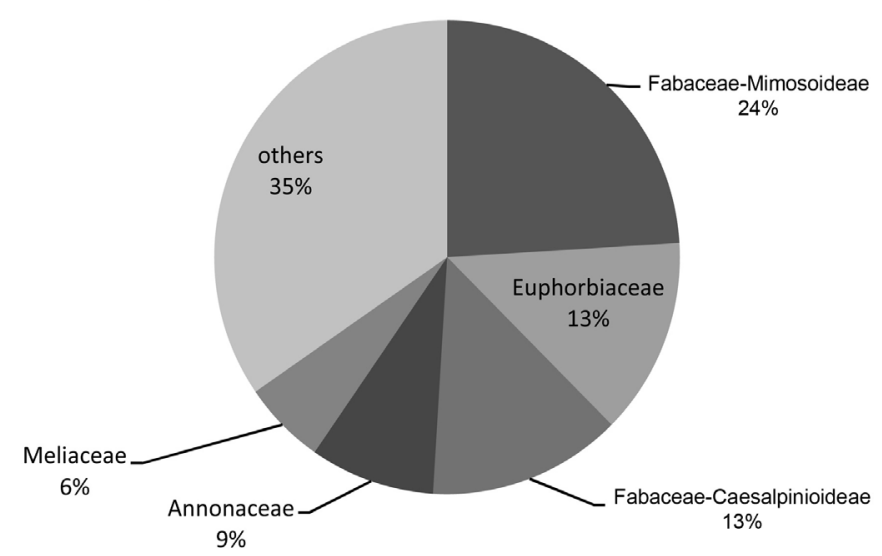

(c)

Figure 3. Proportion of the most represented families in number of species in the 20-year-old block (a). Proportion of most represented families in number of species in the 31-year-old block (b). Proportion of most represented families in number of species in 64-year-old block (c). 
"other" represents the 15 families that each has less than $5 \%$ of species. Figure 3(b) shows that 7 families account for $92 \%$ of the species recorded. The first rank is occupied by the Poaceae family with $27 \%$. In the last row is the family Cucurbitaceae with $5 \%$ of species. Five other families represent $8 \%$ of the listed species. Five out of 24 families represent $65 \%$ of the species found in 20 -year-old blocks (Figure 3(c)). The most represented families are: Fabaceae-Mimosoïdeae (24\%); Euphorbiaceae and Fabaceae-Caesalpinoideae with each 13\%; Annonaceae (9\%); Meliaceae (6\%). Nineteen other families represent 35\% of recorded species.

\subsection{Tree Species Distribution by Diameter Class}

Seventy-eight woody plants identified in the undergrowth of Limba (Terminalia superba Engl. \& Diels) blocks studied and distributed in 28 species (Figure 4) have different physiognomies depending on the diameter. Figure 4 shows the distribution of woody plants in the 64, 31 and 20-year sub-plots by amplitude diameter class 10 .

Figure 4(a) shows that the total number of individuals is 44 trees. The largest number of individuals is represented by class 10 - 20 (13) followed by class 0 - 10 with 6 individuals. Class 80 - 90 was not represented. This Figure 4(a) shows that the diametric distribution of individuals has a decreasing exponential form (equation $y=12.464 \mathrm{e}^{-0.25 x}$ ). Figure $4(\mathrm{~b})$ shows that the largest number of individuals is represented by the 0 - 10 class with 2 individuals followed by the 10 20 class with only 1 individual. Classes from 20 to 120 were not represented. The distribution of individuals by diameter class once again shows a decreasing exponential form (equation $y=4 \mathrm{e}^{-0.693 x}$ ). Figure $4(\mathrm{c})$ shows that the number of individuals is 32. The largest number of individuals is represented by the $0-10$ class with 9 individuals followed by the 20 - 30 class with 7 individuals. Classes from 70 to 120 were not represented unfortunately. The diametric structure of individuals, however, has a decreasing exponential form of equation $y=$ $10.60 \mathrm{e}^{-0.247 x}$. Figure 4 shows in the different diameter classes that the number of individuals decreases with increasing diameter.

\subsection{Biomass and Carbon Stock}

The floristic inventory conducted in the blocks of Terminalia superba Engl. \& Diels of 64, 31 and 20 years of age identified a total of 129 trees of DBH $\geq 5 \mathrm{~cm}$ consisting of 51 trees of Terminalia superba Engl. \& Diels and 78 feet of various species, which allowed the calculation of biomass and carbon stock.

Table 4 presents the distribution of biomass by survey and pool. Table 4 presents the distribution of biomass by survey and pool. Table 4 shows that the largest biomass is represented by the P1 with 55.21 tons. From P2 to P9, a considerable variation of the biomass is observed. Table 5 presents the distribution of biomass and carbon stock by pool, block, sub-plot and species. However, biomass ranged from 46.88 to 131.60 tons in all blocks. The total aboveground 


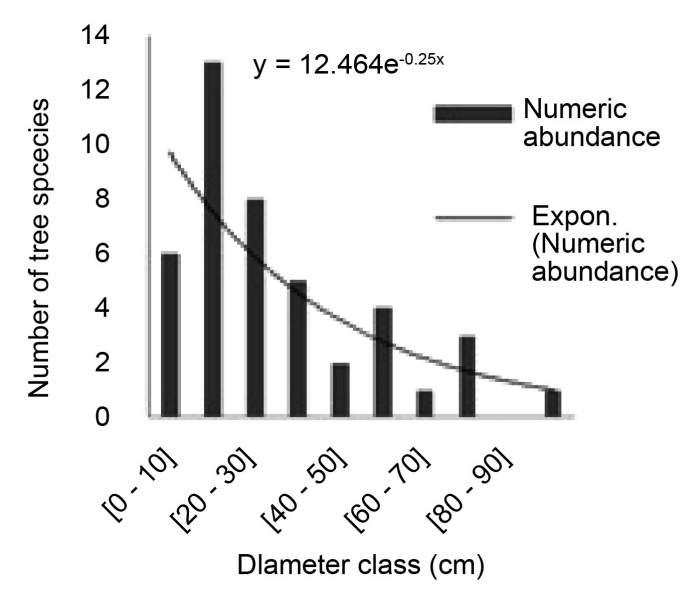

(a)

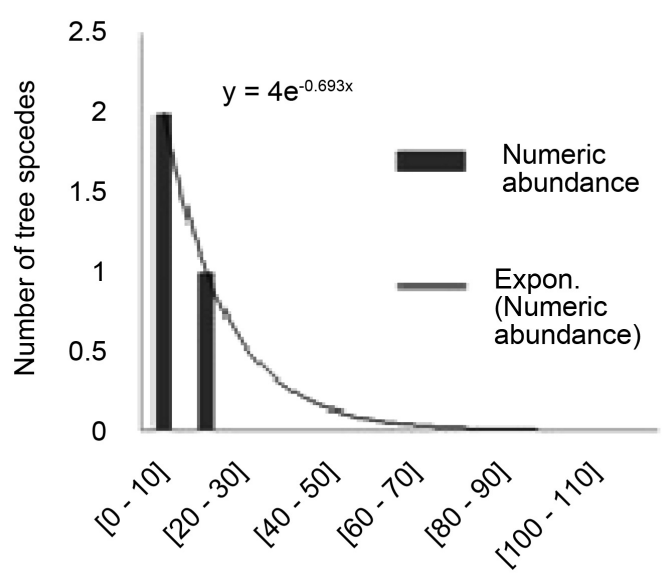

(b)

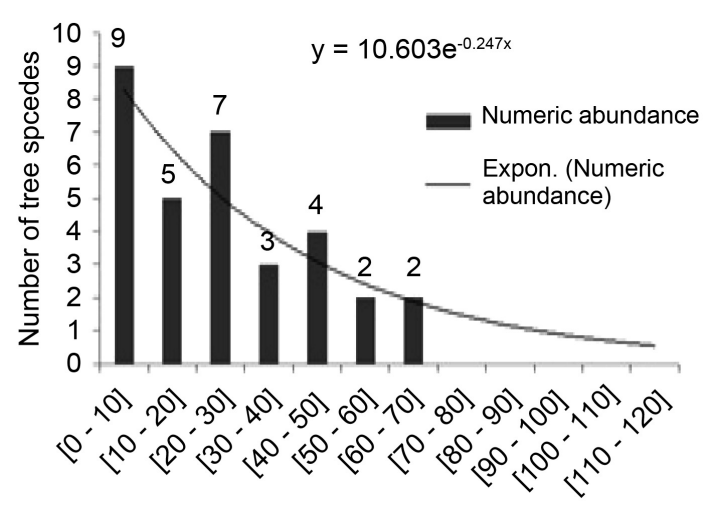

(c)

Figure 4. Distribution of species founded in 64-year-old blocks by diameter class (a); Distribution of identified species in 31-year-old blocks by diameter class (b); Distribution of species recorded in 20 -year-old block by diameter class (c).

biomass was 228.96 tons and total belowground biomass was 46.94 tons (Table 5). Table 5 shows that biomass ranges from 56.49 to 158.58 tons in all blocks. 
Table 4. Biomass distribution by sub-plot (in $\left.t \cdot h a^{-1}\right)$; P: Sub-plot; AGB: aboveground biomass $\left(\mathrm{t} \cdot \mathrm{ha}^{-1}\right)$; BGB: belowground biomass $\left(\mathrm{t} \cdot \mathrm{ha}^{-1}\right)$.

\begin{tabular}{cccccccccc}
\hline Biomass & P1 & P2 & P3 & P4 & P5 & P6 & P7 & P8 & P9 \\
\hline AGB & 45.82 & 12.45 & 44.75 & 14.10 & 13.56 & 22.81 & 0.04 & 22.34 & 13.83 \\
BGB & 3.39 & 2.75 & 9.17 & 2.89 & 2.78 & 4.67 & 0.008 & 4.58 & 2.85 \\
Total & 55.21 & 16.20 & 53.93 & 16.99 & 16.34 & 27.8 & 0.051 & 26.92 & 16.66 \\
\hline
\end{tabular}

Table 5. Biomass and carbon stock distribution in study area by forest age. AGB: Trees aboveground biomass ( $\left.\mathrm{t} \cdot \mathrm{ha}^{-1}\right)$; BGB: Trees belowground biomass $\left(\mathrm{t} \cdot \mathrm{ha}^{-1}\right)$; Biomass: Total trees biomass $\left(\mathrm{t} \cdot \mathrm{ha}^{-1}\right)$; Carbon: Total carbon stock $\left(\mathrm{t} \cdot \mathrm{ha}^{-1}\right)$; Block: Block of planted forest by age (in year).

\begin{tabular}{ccccc}
\hline Block & AGB & BGB & Biomass & Carbon \\
\hline 64 & 131.60 & 26.98 & 158.58 & 74.53 \\
31 & 50.48 & 10.35 & 60.82 & 28.58 \\
20 & 46.88 & 9.61 & 56.49 & 26.55 \\
Total & $\mathbf{2 2 8 . 9 6}$ & $\mathbf{4 6 . 9 4}$ & $\mathbf{2 7 5 . 8 9}$ & $\mathbf{1 2 9 . 6 7}$ \\
\hline
\end{tabular}

The largest biomass is represented by the oldest block (64 years) followed by the block of 31 years $\left(60.82 \mathrm{t} \cdot \mathrm{ha}^{-1}\right)$ and lastly the stand of 20 years $\left(56.49 \mathrm{t} \cdot \mathrm{ha}^{-1}\right)$. This Table 5 shows that the biomass varies with the age of the block. This distribution of biomass is also observed for the carbon stock.

With regard to the distribution of carbon stock per sub-plot, P1 sequestered more than 25 tons of carbon, followed by the P3 with a stock of 25.35 tons. In this ecosystem, for Limba (Terminalia superba Engl. \& Diels) we recorded $181.42 \mathrm{t} \cdot \mathrm{ha}^{-1}$ of biomass, or $85.27 \mathrm{t} \cdot \mathrm{ha}^{-1}$ of carbon stock. For other species, we recorded $96.53 \mathrm{t} \cdot \mathrm{ha}^{-1}$ of biomass, or $19.79 \mathrm{t} \cdot \mathrm{ha}^{-1}$ of carbon stock. The total biomass of the study area was 275.89 tons and the carbon stock 129.67 tons of carbon. The quantity of $\mathrm{CO}_{2}$ captured in the atmosphere by the identified plant procession deducted from this carbon stock has been 475.89 tons of $\mathrm{CO}_{2}$, an economic value equal to US $\$ 2379.45$ or XAF 1,413,278.

For distribution by diameter class of the carbon stock recorded at the 64-year block level, the largest value is represented by the class $50-60 \mathrm{~cm}\left(36.97 \mathrm{t} \cdot \mathrm{ha}^{-1}\right)$ followed by the $70-80 \mathrm{~cm}$ class $\left(36.51 \mathrm{t} \cdot \mathrm{ha}^{-1}\right)$. The class of 100 to 110 was unfortunately not represented. For Distribution by diameter class of carbon stock sequestered by the 31-year-old block, the $60-70 \mathrm{~cm}\left(18.78 \mathrm{t} \cdot \mathrm{ha}^{-1}\right)$ class sequestered the largest carbon stock, followed by class $30-40 \mathrm{~cm}\left(12.97 \mathrm{t} \cdot \mathrm{ha}^{-1}\right)$. Classes $80-90,90-100,100-110$ and $110-120$ have unfortunately not been represented. For the diameter class distribution of carbon sequestered by the 20-year-old block, the largest carbon stock was sequestered by the $40-50 \mathrm{~cm}$ diameter class $\left(23.02 \mathrm{t} \cdot \mathrm{ha}^{-1}\right)$. Diameter classes of $0-10$ and $70-120$ were not represented. However, for the height class distribution of the carbon stock recorded in this ecosystem, the distribution pattern of the carbon stock has been the same for all three blocks. The largest value of the carbon stock was represented by the class $30-40 \mathrm{~m}$, followed by class classes $20-30 \mathrm{~m}, 10-20 \mathrm{~m}$ and $0-10 \mathrm{~m}$. 
Classes $40-50 \mathrm{~m}$ and $50-60 \mathrm{~m}$ were not represented in the blocks of 31 and 20 years.

\subsection{Survival Rate}

This study shows different survival rates (4). The sub-plot1 has a survival rate of $100 \%$ followed by the second row P2 with a rate of 75\%. P7, P9 and P8 with respectively $66.67 \%, 44.44 \%$ and $44.44 \%$ survival rate, high values compared to $\mathrm{P} 4$, P5 and P6 with respectively 30\%, 26.67\% and 36.67\%. The monospecific stands of 64,31 and 20 years represent the respective survival rates of $75 \%, 30 \%$ and $55.55 \%$.

\section{Discussion}

\subsection{Dendrology and Survival Rate State}

This study carried out within the Limba (Terminalia superba Engl. \& Diels) plantations of 64, 31 and 20 years, allowed us to record respectively 9, 27 and 15 alive floras. These alive floras counts correspond to a survival rate of $75 \%, 30 \%$ and $55.55 \%$ respectively for blocks of 64,31 and 20 years. The study conducted by [17] in the plot of Aucoumea klaineana Pierre with an area of 1.4 ha shows a survival rate of $44.05 \%$. Thus, [17] stated that this rate is explained by a poor monitoring of the plot once the plants were installed. Regarding our study, the different survival rates recorded in the blocks of Terminalia superba Engl. \& Diels highlighted is explained in various ways.

In fact, the 64-year-old block installed by a silvicultural method of artificial regeneration consisting in destroying the existing vegetation and then reforesting it, has given very good results as testifies Mr. Bakala, former worker of the OCF Company. He added that regular talks were given to his reforestation. Given this testimony, it's clear to reject the hypothesis of poor monitoring of the block. However, this survival rate of $75 \%$ can be granted to large-scale anthropogenic actions in these blocks. This plantation is the most disturbed of our study, 3 strains found on the spot in the sub-plots 2 and sub-plot3 confirm the slaughter of 3 trees. As for the 31-year-old block, it was set up in a swampy area and at a distance of $5 \mathrm{~m}$ by $5 \mathrm{~m}$ by a method of total destruction of the wild gallery forest. This block has the lowest survival rate of the study (30\%). This plot located in Bilala $100 \mathrm{~m}$ from the administrative building of the station to protect the soil of the creek "gutter" against erosion, remains immune to human disturbance. However, the factors that may cause this survival rate may be soil type and planting spacing.

\subsection{Floristic Diversity Assessment}

In terms of biodiversity conservation, the indicator commonly used is the specific richness that determines the state of degradation of an ecosystem. Overall, the plant procession studied reported 62 species, or around 3586 individuals belonging to 36 families. Species richness varies from one survey to another from 6 
to 19 species. The Shannon diversity index and Pielou evenness ranged from 1.30 to 2.44 bits and 0.35 to 0.77 , respectively, in all Terminalia superba Engl. \& Diels surveys. In the fallow field, the diversity has been very important with a value of 3.02 compared to the records of Terminalia superba Engl. \& Diels.

In all blocks of Terminalia superba Engl. \& Diels, species richness ranges from 12 to 33 species. The greatest species richness was observed in 20 -year-old blocks followed by 64-year-old blocks with 27 species. These two blocks of 64 and 20 years have a high number in terms of species compared to fallow field which has 18 species. This richness of 18 species was greater than that obtained in block of 31 years (12 species). These results do not corroborate those of [37] where the number of species increases with block age. [37] further reveals that floristic wealth is conditioned mainly by ecological conditions and anthropogenic disturbances [37].

It is reasonable to say, however, that activities within the 64-year-old block have had an impact on forest recovery. These differences can also be explained by the silvicultural method applied for each block. Indeed, the 20-year-old block has been set up right in the heart of a gallery forest by Professor Aubreville's technique of opening strips, which partially destroys existing vegetation. This block is very stable; no activity has been identified within this block. The 31-year-old and 64-year-old block were established by the destruction of the existing forest, which had a negative impact on forest recovery. The 31-year-old stand was established in a flooded area while [38] noted that wetlands have relatively low species richness.

Shannon indices range from 1.81 to 1.97 bits in all three stands. The Pielou index varies from 0.47 to 0.61 . The highest average value of the Pielou index goes back to the 31-year-old plot. These strong values reflect a great diversity and a possible reconstitution of forest. These results are superior to those found by [39] in monocultures of Eucalyptus and Pines (0.38 to 0.89 bits). Differences in silvicultural crops and the age of their blocks could explain the differences between their indices.

Resettlement can also be characterized by the structural distribution of individuals by diameter classes [37]. It appears from this study that the individuals surveyed are highly concentrated in numbers in small diameter classes. The largest number of individuals is represented by the 10 - 20 class for the 64 year old block and 0 - 10 in the 31 and 20-year-old blocks. In all blocks of Terminalia superba Engl. \& Diels, the distribution of individuals by diameter class has a decreasing exponential form. The number of individuals per diameter class decreases with the increase in diameter reminiscent of a recent block and good regeneration of vegetation. This distribution corroborates with the works from [37] [40] [41]; where the general trend shows a distribution with more important numbers for trees of small diameters.

\subsection{Trees Biomass and Carbon Stock}

One hundred and twenty-nine floras of $\mathrm{DBH} \geq 5 \mathrm{~cm}$, estimated the biomass of 
the block at 275.89 tons divided into two pools: aboveground pool was 228.96 tons and that of the belowground pool was 46.94 tons. In all the plots, this biomass varies from 0.051 to 55.21 . This is explained by the fact that the plots studied do not have the same physiognomy.

However, biomass varies from 56.49 to 158.58 tons in all the blocks studied. The largest biomass was represented by the oldest block (64 years) followed by the block of 31 years and lastly the block of 20 years. These differences are due to the diversity of each block and the specific density of the inventoried trees. These results corroborate with the study conducted by [42], in the agroforestry systems of cocoa plantation from 5 to 15 years, where biomass increases with the age of planting [42].

The carbon stock sequestered by all studied block was 129.67 tons of carbon. It ranges from 26.55 to 74.53 tons of carbon throughout the block. The largest carbon stock was sequestered by the Terminalia superba Engl. \& Diels block with a value of 85.27 tons. The other 27 species represent a carbon stock of 19.27 tons of carbon. This difference is likely related to the diametric structure, sequestration capacity, and age of species that have been identified. The amount of $\mathrm{CO}_{2}$ captured in the atmosphere by the plant procession is 475.89 tons $\mathrm{CO}_{2}$ equivalent, an economic value equal to USD 2379.45 or XAF $1,413,278$. This economic value obtained in 2018 is very fluctuating. The price of a ton of carbon in the carbon market is oscillating.

\section{Conclusion}

This work has shown that other forest species can exist in a monodominant forest of Terminalia superba Engl. \& Diels. The distribution of exhausted flora according to diameter classes shows that stems with a diameter of less than $10 \mathrm{~cm}$ accumulate a total of 43 individuals while large diameter exhausted flora becomes rare. This presence of small diameter stems shows that the sub-plots studied have several individuals with a future to ensure regeneration. It is therefore appropriate to state that the vegetation of the undergrowth of Terminalia superba Engl. \& Diels evolves towards the characteristics of the natural forest. Recolonization of exhausted flora by the forest is rapid. In the long term, this will probably lead to an installation of the climax forest; particularly the heliophilous species such as Ricinodendron heudelotii (Baill.) Pierre ex Heckel, Musanga cecropioides R.Br., etc., already reflect this phenomenon. The total biomass has been 275.89 tons and the carbon stock has been 129.67 tons of carbon corresponding to an amount of 475.89 tons of carbon dioxide equivalent, which is an economic value equal to XAF $1,413,278$. This study has shown that strong anthropogenic disturbances play a very detrimental role in forest recovery, which prevents the development of trees and the generation of carbon stocks. This study highlighted the reforestation of Terminalia superba Engl. \& Diels in its floristic diversity, which contributes to fight against the climate change. Finally, it proposes socio-economic integration of the local population of Bilala into 
agroforestry projects in order to diversify the activities of SNR, which generates spinoffs that can overcome the economic crisis to which the structure and population of Bilala are confronted with.

\section{Acknowledgements}

The authors would like to thank National Superior School for Agronomy and Forestry (Ecole Nationale Superieure d'Agronomie et de Foresterie-ENSAF) from Marien Ngouabi University (Université Marien Ngouabi) for supporting this study. Reforestation National Service (SNR) from Congolese Ministry of Forest Economy also supported this work. We greatly acknowledge Joseph Faustin Dembi, Guy Julien Kazotti and Gad Kinouani from Reforestation National Service (Service National de Reboisement-SNR) for providing facilities about field measurements in Bilala. Different anonymous referees have provided substantial contribution and the authors address to them their heartfelt thanks.

\section{Conflicts of Interest}

The authors declare that there is no conflict of interests regarding this paper.

\section{Additional Information}

Supplementary material related to this paper is available online at: http://www.scirp.org/journal/OALibJ/.

\section{References}

[1] CDB (2010) Third Edition of Global Perspective on Biodiversity. Convention on Biological Diversity. Montreal.

[2] Pan, Y., Birdsey, R.A., Fang, J., Houghton, R., Kauppi, P.E., Kurz, W.A. and Phillips, O.L. (2011) A Large and Persistent Carbon Sink in the World. Science, 333, 988-993. https://doi.org/10.1126/science.1201609

[3] PEFC (2017) European Program for Forest Certification. https://www.pefc-france.org/la-gestion-durable-de-la-foret

[4] FAO (2005) Press Communication: Deforestation Is Growing with an Alarming Rate. Food and Agriculture Organization for United Nations, Rome.

[5] Robert, B. (2006) From National Natural History Museum, the Elephant in the Game of the Skittle. Seuil, Ardennes.

[6] Van Der Werf, G.R., Morton, D.C., Defries, R.S., Olivier, J.G.J., Kasibhatla, P.S. and Jackson (2009) $\mathrm{CO}_{2}$ Emissions from Forest Loss. Nature Geoscience, 2, 737-738. https://doi.org/10.1038/ngeo671

[7] Laurent, D. and Maitre, H.F. (1992) Destruction of Tropical Forest Resources: Logging Is a Cause? CTFT/FAO, Rome.

[8] Ngoumba, B.Y. (2019) Biodiversity, Estimation of Carbon Stock and Forest Management for Terminalia superba Engl. \& Diels Reforestation in Bilala (Kouilou Department). Master Memory. National Superior School for Agronomy and Forestry. Marien Ngouabi University, Brazzaville.

[9] Saya, A., Marien, J.N. and Mallet, B. (2016) Planted Forests for the Area Management: Case of Plantations in Republic of Congo. CRDPI, CIRAD. 
[10] Ekoungoulou, R., Liu, X.D., Loumeto, J.J., Ifo, S.A., Bocko, Y.E., Koula, F.E. and Niu, S.K. (2014) Tree Allometry in Tropical Forest of Congo for Carbon Stocks Estimation in Above-Ground Biomass. Open Journal of Forestry, 4, 481-491. https://doi.org/10.4236/ojf.2014.45052

[11] Ekoungoulou, R., Niu, S.K., Folega, F., Nzala, D. and Liu, X.D. (2018) Carbon Stocks of Coarse Woody Debris in Central African Tropical Forests. Sustainability in Environment, 3, 142-160. https://doi.org/10.22158/se.v3n2p142

[12] Jonard, M., Colmant, R. and Heylen, C. (2014) Impact of Coniferous Forestation on Carbon Sequestration of Peruvian Andes: Case of Pinus patula Plantations in the Cooperative of Granja Porcon (Cajamarca), Perou. Bois et Forêts des Tropiques, 322, 17-27. https://doi.org/10.19182/bft2014.322.a31226

[13] Boundzanga, G.C. (2018) Dendrometrical Work to a Better Evaluation of Rough and Net Comercial Volumes of Trees in Republic of Congo's Forest Concession. CN-REDD, Brazzaville.

[14] Ekoungoulou, R., Liu X.D., Loumeto, J.J. and Ifo, S.A. (2014) Tree Above-And Below-Ground Biomass Allometries for Carbon Stocks Estimation in Secondary Forest of Congo. Journal of Environmental Science, Toxicology and Food Technology, 8, 9-20. https://doi.org/10.9790/2402-08420920

[15] Ekoungoulou, R., Liu, X.D., Ifo, S.A., Loumeto, J.J. and Folega, F. (2014) Carbon Stock Estimation in Secondary Forest and Gallery Forest of Congo Using Allometric Equations. International Journal of Scientific and Technology Research, 3, 465-474.

[16] Kimpouni, V., Loumeto, J.L. and Mizingou, J. (2008) Floristic Diversity of Forest Facies of Aucoumea klaineana (Okoume) in the Congolese Littoral. Acta Botanica Gallic. Botany Letters, 153, 323-334. https://doi.org/10.1080/12538078.2008.10516113

[17] Boukono, D.R.V. (2018) Estimation of Carbon Stock in a Block of Okoumea klaineana from the Reforestation National Service. Bachelor Memory. National Superior School for Agronomy and Forestry, Brazzaville.

[18] Ekoungoulou, R., Niu, S.K., Loumeto, J.J., Ifo, S.A., Bocko, Y.E., Mikieleko, F.E.K., Guiekisse, E.D.M., Senou, H. and Liu, X.D. (2015) Evaluating the Carbon Stock in Above-And Below-Ground Biomass in a Moist Central African Forest. Applied Ecology and Environmental Sciences, 3, 51-59.

[19] Moutsambote, J.M., Nzala, D. and Ngondo, J.C. (2000) Evolution of Forest Exhausted after Cassava Production in Mayombe. Cahiers Agricultures, 9, 141-144.

[20] Goma-Tchimbakala, J., Ndondou-Hockemba, M., Kokolo, A. and Mboussou-Kimbangou, A.N.S. (2005) Variations on Litter Bringing and Mineral Component in the Limba (Terminalia superba) Plantation in Congo. Tropicultura, 23, 53-59.

[21] ANAC (2018) Annual Report of National Agency of Civil Aviation. National Agency of Civil Aviation (ANAC), Brazzaville.

[22] Pearson, T.S. and Brown, S. (2005) Guide for Measuring and Monitoring Carbon in Forests and Grasslands. Winrock International, Arlington.

[23] ATIBT (2006) Botanic-Inventory Biodiversity. Volume VIII, Association of International Technicians on Tropical Timbers, Libreville.

[24] CNIAF (2016) List of Inventoried Flora in Southern Congo. National Center of Inventory and Management of Wildlife and Forest Resources. Brazzaville.

[25] Pedel, L. and Fabri, M.C. (2012) Art State on Existing Index Concerning Ecological State of Benthic Habitats of Deep Domain. Laboratory of Environment Resources 
(LER). MEDDTL Convention, Ifremer for DCSMM, BEE.

[26] Ekoungoulou, R., Nzala, D., Liu, X.D. and Niu, S.K. (2017) Ecological and Structural Analyses of Trees in an Evergreen Lowland Congo Basin Forest. International Journal of Biology, 10, 31-43. https://doi.org/10.5539/ijb.v10n1p31

[27] Ekoungoulou, R., Folega, F., Mukete, B., Ifo, S.A., Loumeto, J.J., Liu, X.D. and Niu, S.K. (2018) Assessing the Effectiveness of Protected Areas on Floristic Diversity in Tropical Forests. Applied Ecology and Environmental Research, 16, 837-853. https://doi.org/10.15666/aeer/1601_837853

[28] Ekoungoulou, R. (2014) Carbon Stocks Evaluation in Tropical Forest, Congo. Carbon Stocks in Forest Ecosystems. Lambert Academic Publishing, Saarbrucken.

[29] Ekoungoulou, R. (2018) Managing Tropical Forest Ecosystems. Tropical Trees. Lambert Academic Publishing, Saarbrucken.

[30] Chave, J., Rejou-Mechain, M., Burquez, A., Chidumayo, E., Colgan, M.S., Delitti, W.B.C., Duque, A., Eid, T., Fearnside, P.M., Goodman, R.C., Henry, M., Martinez-Yrizar, A., Mugasha, W.A., Muller-Landau, H.C., Mencuccini, M., Nelson, B.W., Ngomanda, A., Nogueira, E.M., Ortiz-Malavassi, E., Pelissier, R., Ploton, P., Ryan, C.M., Saldarriaga, J.G. and Vieilledent, G. (2014) Improved Allometric Models to Estimate the Aboveground Biomass of Tropical Trees. Global Change Biology, 20, 3177-3190. https://doi.org/10.1111/gcb.12629

[31] Djomo, A.N., Picard, N., Fayolle, A., Henry, M., Ngomanda, A., Ploton, P., McLellan, J., Saborowski, J., Adamou, I. and Lejeune, P. (2016) Tree Allometry for Estimation of Carbon Stocks in African Tropical Forests. Forestry, 89, 446-455. https://doi.org/10.1093/forestry/cpw025

[32] Ekoungoulou, R., Nzala, D., Liu, X.D. and Niu, S.K. (2018) Tree Biomass Estimation in Central African Forests Using Allometric Models. Open Journal of Ecology, 8, 209-237. https://doi.org/10.4236/oje.2018.83014

[33] Fayolle, A., Loubota, P.G.J., Drouet, T., Swaine, M.D., Bauwens, S., Vleminckx, J., Biwole, A., Lejeune, P. and Doucet, J.L. (2016) Taller Trees, Denser Stands and Greater Biomass in Semi-Deciduous than in Evergreen Lowland Central African Forests. Forest Ecology and Management, 374, 42-50. https://doi.org/10.1016/j.foreco.2016.04.033

[34] Mokany, K., Raison, R.J. and Prokushkin, A.S. (2006) Critical Analysis of Root: Shoot Ratios in Terrestrial Biomes. Global Change Biology, 12, 84-96. https://doi.org/10.1111/j.1365-2486.2005.001043.x

[35] IPCC (2006) The 2006 Directrix Line of International Panel on Climate Change (IPCC) for the Nationals Inventories of Greenhouse Gas. Agriculture, Forestry and Others Earth Affections. Chapter 3: Earth Coherent Representation.

[36] EMP (2018) State of the Voluntary Carbon Market. Ecosystem Services. Ecosystems Marketplace. http://www.ecosystemmarketplace.com

[37] Awe, D.V. (2016) Diversity Floristic and Carbon Stock in the Plantation of Anacardium. Master Memory in Plant Organisms Biology. University of Ngaoundere, Ngaoundere.

[38] Tareil, J. and Groulez, J. (1958) Limba Plantations of Moyen Congo. Bois et Forêts des Tropiques, 61, 9-25. https://doi.org/10.19182/bft1958.61.a18715

[39] Nzala, D., Nongamani, A., Moutsambote, J. and Mapangui, A. (1997) Floristic Diversity in the Monocultures of Eucalyptus Pine in Congo. Cahiers Agricultures, 6, 169-174.

[40] Adamou, M.B. (2010) Biodiversity and Carbon Sequestration in Cocoa Plantation at 
the West Periphery of Lobeke National Park. Master Memory. University of Yaounde, Yaounde.

[41] Tsoumou, B.R., Lumande, K.J., Kampe, J.P. and Nzila, J.D. (2016) Estimation of Carbon Stock Sequestred by Dimonika Reference Forest (Southwestern Republic of Congo). Revue Scientifique et Technique Foret et Environnement du Bassin du Congo, 6, 39-45.

[42] Temgoua, L.F., Dongmo, W., Nguimdo, V. and Nguena, C. (2018) Ligneous Diversity and Carbon Stock of Agroforestry System Based on Cocoa Plantations at East of Cameroon. Journal of Applied Biosciences, 122, 12274-12286.

https://doi.org/10.4314/jab.v122i1.7 